IZA DP No. 192

\title{
Absolute Risk Aversion and the Returns to Education
}

Giorgio Brunello

August 2000 


\title{
Absolute Risk Aversion and the Returns to Education
}

\author{
Giorgio Brunello \\ Department of Economics, University of Padua, CESifo, Munich and IZA, Bonn
}

Discussion Paper No. 192

August 2000

\author{
IZA \\ P.O. Box 7240 \\ D-53072 Bonn \\ Germany \\ Tel.: +49-228-3894-0 \\ Fax: +49-228-3894-210 \\ Email: iza@iza.org
}

This Discussion Paper is issued within the framework of IZA's research area The Future of Work. Any opinions expressed here are those of the author(s) and not those of the institute. Research disseminated by IZA may include views on policy, but the institute itself takes no institutional policy positions.

The Institute for the Study of Labor (IZA) in Bonn is a local and virtual international research center and a place of communication between science, politics and business. IZA is an independent, nonprofit limited liability company (Gesellschaft mit beschränkter Haftung) supported by the Deutsche Post AG. The center is associated with the University of Bonn and offers a stimulating research environment through its research networks, research support, and visitors and doctoral programs. IZA engages in (i) original and internationally competitive research in all fields of labor economics, (ii) development of policy concepts, and (iii) dissemination of research results and concepts to the interested public. The current research program deals with (1) mobility and flexibility of labor markets, (2) internationalization of labor markets and European integration, (3) the welfare state and labor markets, (4) labor markets in transition, (5) the future of work, (6) project evaluation and (7) general labor economics.

IZA Discussion Papers often represent preliminary work and are circulated to encourage discussion. Citation of such a paper should account for its provisional character. 
IZA Discussion Paper No. 192

August 2000

\section{ABSTRACT}

\section{Absolute Risk Aversion and the Returns to Education*}

Individual absolute risk aversion is measured for a sample of 1373 male household heads, using the 1995 wave of the Survey on the Income and Wealth of Italian households. This measure, conditional on financial and real wealth and household income, is used as an instrument for attained education in a standard log earnings equation. I find that, in line with the literature, the gap between IV and OLS estimates of the returns to education is large.

JEL Classification: J24, J31

Keywords: Returns to education, instrumental variables

Giorgio Brunello

Department of Economics

University of Padua

Via del Santo 33

I - 35100 Padua

Tel.: +39 (0)49 827-4223

Fax : +39 (0)49 827-4211/4221

Email: brunello@decon.unipd.it

\footnotetext{
* I am grateful to Daniele Checchi, Luigi Guiso, Tullio Jappelli, Guglielmo Weber and in particular to
} Claudio Lucifora for advice. The usual disclaimer applies. 


\section{Introduction}

It is well known that the estimation of the returns to education is difficult both because of measurement error and because unobserved ability can affect both educational choice and the returns to education. One of the strategies used to deal with this problem consists of selecting instrumental variables, that are correlated with schooling but not with earnings (conditional on schooling). The typical instruments used in the literature are school reforms, family background variables and smoking. An alternative is to use data on twins. See Card (1999) for a review of the existing evidence. In this note I add to the current list an additional candidate, the absolute degree of risk aversion. I start by showing in a simple static model that risk aversion affects in a natural way educational choice by influencing the marginal utility of schooling. Perhaps one reason why this variable has not been used so far is that it is difficult to measure risk aversion in survey data (see Barsky et al (1997) for an attempt). I use the 1995 wave of the Survey on the Income and Wealth of Italian households and previous work on these data by Guiso and Paiella (2000) to measure individual absolute risk aversion in a sample of 1373 married Italian male household heads. This variable is then used as an instrument for education in a standard Mincerian earnings function. In line with most of the current literature, I find that the gap between IV and OLS estimates is substantial.

\section{Schooling Choice}

Following Card (1999) I assume that an individual chooses $S$, the years of schooling, in order to maximize the following utility function ${ }^{1}$

$$
U(y)-\phi(S)
$$

where $y$ is (hourly) earnings, $U$ is a concave function and $\phi$ is a convex function of $S$. Hourly earnings are related to $S$ by the following function

$$
y=g(S)=e^{\lambda S}
$$

The first order condition associated to the maximization of (1) is

$$
U^{\prime} g^{\prime}(S)=\phi^{\prime}(S)
$$

where the prime if for the first order derivative ${ }^{2}$.

Using a first order Taylor approximation of $U^{\prime}$ around $y=0$, Eq. (3) can be re-written as follows

$$
U^{\prime}(0)[1-A R A g(S)] g^{\prime}(S)=\phi^{\prime}(S)
$$

\footnotetext{
${ }^{1}$ This assumption ignores the importance of parental choice in the education of children.

${ }^{2}$ The sufficient condition for an interior maximum is

$$
U^{\prime \prime} g^{\prime}(S)^{2}+U^{\prime} g^{\prime \prime}(S)-\phi^{\prime \prime}(S)<0
$$
}


where $A R A$ is the Arrow Pratt coefficient of absolute risk aversion (see Laffont (1990)). Let $\phi^{\prime}(S)=r$, the marginal cost of an additional year of schooling. If the utility function belongs to the CARA class and

$$
U(y)=-\frac{1}{\sigma} \exp (-\sigma y)
$$

the coefficient $A R A$ is equal to $\sigma^{3}$ and schooling choice is given by

$$
S^{*}=S(\lambda, r, \sigma)
$$

Claim 1 The selected years of schooling $S$ decrease when absolute risk aversion ARA increases.

P roof. Differentiation of (4) with respect to $A R A$ and $S$ yields $1 / 2$

$$
g^{\prime \prime}(S)\left(1-A R A g(S)-A R A g^{\prime}(S)^{2}-{\frac{\phi^{\prime \prime}(S)^{3 / 4}}{U^{\prime}(0)}}^{3 / 2} \partial S=g(S) g^{\prime}(S) \partial A R A\right.
$$

The expression within parentheses is negative because of the second order conditions for a maximum.

Individual differences in educational attainment can be explained in this simple model both by differences in marginal returns $\lambda$ and marginal costs $r$ and by differences in the absolute degree of risk aversion.

\section{The Empirical Model}

Consider the standard regression model

$$
\begin{gathered}
\ln y=\alpha_{0}+\alpha_{1} S+\alpha_{2} A+\alpha_{3} A^{2}+\varepsilon \\
S=X \beta+Z \gamma+\eta
\end{gathered}
$$

where $A$ is age, $\varepsilon$ and $\eta$ are error terms, (7) is the Mincerian earnings function ${ }^{4}$ and (8) is the attainment function, that depends both on variables affecting marginal benefits $(X)$ and on variables affecting marginal costs and measuring individual preferences $(Z)$.

It is well known that the ordinary least squares (OLS) estimate of (7) yields a consistent estimate of $\alpha_{1}$ only when $\varepsilon$ and $\eta$ are uncorrelated. Unobserved ability and measurement error are two well known factors that affect both schooling $S$ and earnings $y$ conditional on schooling. This problem can be dealt with by identifying a set of variables that affect schooling but not (conditional) earnings.

\footnotetext{
${ }^{3}$ Card uses a CRRA utility function $U(y)=\ln y$.

${ }^{4} \mathrm{I}$ use age rather than potential experience because the former variable can be treated as exogenous. See Harmon and Walker (1995).
} 
These variables can be used as instrumental variables (IV) to estimate returns to education.

Card (1999) presents a detailed review of previous studies based on instrumental variables and discusses the validity of the instruments used in each study. Briefly, these instruments include school reforms and features of the school system, family background and the use of samples of twins. Another instrument recently used but not discussed by Card is smoking. The argument here is that smoking habits are likely to be highly correlated with the discount rate, that affects $r$, but do not influence earnings directly ${ }^{5}$. Therefore, they can be used as a valid instrument for schooling $S$.

The simple model presented in the previous section suggests that a measure of individual absolute risk aversion $A R A$ is another potential candidate. In the model, the variable $A R A$ affects the schooling decision because it affects the marginal utility of income, but does not affect the marginal returns to schooling $\lambda$.

\section{M easuring risk aversion}

Following Laffont (1990), the coefficient of absolute risk aversion at a given level of wealth $W$ is twice the risk premium per unit of variance for small risk. The risk premium is the maximum amount that an agent is willing to pay to have the sure return rather than the expected return from a lottery ticket. According to this definition, risk aversion is not easy to measure and this perhaps explains why it has never been used as an instrument for attained education. A survey that contains detailed information on individual attitudes towards risk is the Italian Survey on Household Income and Wealth $(S H I W)$, conducted every two years by the Bank of Italy. The survey is very useful for my purpose because it includes information on earnings, educational attainment, household wealth and attitudes towards risk for a nationally representative sample of households.

In the survey, each household head is offered a hypothetical lottery and is asked to report the maximum price that he would be willing to pay to participate $^{6}$. The exact question is

"We would like to ask you a hypothetical question that we would like you to answer as if the situation was a real one. You are offered the opportunity of acquiring a security permitting you, with the same probability $1 / 2$, to either gain 10 million lire or to gain nothing. What is the most that you are prepared to pay for this security?"

Ten million lire corresponds to just over Euros 5,000 (or roughly $\$ 5,000$ ). Guiso and Paiella (2000) explain that the interviews were conducted personally by professional interviewers. In order to help the respondent understand the question, they were supposed to show an illustrative card and to provide

\footnotetext{
${ }^{5}$ See Fersterer and Winter-Ebmer (2000) for a recent discussion.

${ }^{6}$ This section draws extensively from Guiso and Paiella (2000).
} 
explanations. The respondent could answer in one of three ways: a) declare the maximum amount he is willing to pay to participate, denoted here by $M$, known as the compensating certainty equivalent; b) don't know; c) unwilling to answer ${ }^{7}$.

Using the information provided by the answers to this question we can measure the Arrow-Pratt index of absolute risk aversion for each household head. Let $W$ denote the non-random household endowment and $\Pi$ denote the random prize of the lottery, taking values 10 million lire and 0 with equal probability. The maximum entry price is given by:

$$
U(W)=\frac{1}{2} U(W+10-M)+\frac{1}{2} U(W-M)
$$

Taking a second-order Taylor expansion of the right-hand side of (9) around $W$ yields

$$
A R A=4(5-M))^{\mathfrak{f}} 10^{2}+2 M^{2}-20 M^{\not \mathfrak{a}}
$$

that uniquely defines the Arrow-Pratt measure of absolute risk aversion in terms of the parameters of the lottery in the survey.

For the current purpose, a problem with this measure of absolute risk aversion is that it could vary with individual wealth. Laffont (1990) argues that "..it is difficult to obtain sufficient information about an agent's preferences in order to know whether his absolute risk aversion increases or decreases.. [with wealth]. However, .....since we must assume that absolute risk aversion decreases with wealth to obtain results that accord with both intuition and observations of rational behavior..we can infer that agents must satisfy this assumption in general..." (p.24).

Clearly, if absolute risk aversion varies with household wealth, and wealth is correlated with hourly (net) earnings, the variable $A R A$ fails to meet the fundamental requirement for an instrumental variable and cannot be used as a valid instrument for schooling $S$. The availability of detailed information on household income and real and financial wealth in the $S H I W$ dataset, however, allow me to regress individual $A R A$ on these measures of wealth and to use the residuals of this regression as instruments for schooling. Define this generated variable as $R I S K$. By construction, $R I S K$ is orthogonal to household wealth and reflect both individual differences in characteristics (age, education and region of birth) and innate differences in tastes.

A second problem is that absolute risk aversion can affect log earnings of individuals with the same educational attainment by influencing their occupational choice. For instance, individuals with lower risk aversion could choose

\footnotetext{
${ }^{7}$ Guiso and Paiella (2000) find that the sample selection effects induced by missing answers are small and unlikely to constitute a problem.
} 
riskier occupations, that yield higher expected income. In this case, the generated variable $R I S K$ is not a valid instrument. I evaluate this possibility by estimating an ordered probit model of occupational choice and by checking whether RISK significantly affects selection.

A third problem is that educational choice depends on absolute risk aversion at the time of the choice, not on current risk aversion. Therefore, my measure of risk aversion is meaningful only if the time invariant component of risk is important. Empirical evidence in support of the importance of innate preferences is provided by Guiso and Paiella (2000), who find that the main predictor of absolute risk aversion in the $S H I W$ sample is region of birth.

Finally, there is no particular reason to expect that risk aversion, conditional on household wealth, be correlated with unmeasured ability. The maintained hypothesis used in the model, that is kept also in the empirical exercise, is that the causal relation runs from absolute risk aversion to educational attainment, not viceversa.

\section{Empirical Results}

I estimate (7) on the sample of married male household heads aged between 30 and 55 years with at least primary education, who were employed full-time and for the full year in 1995. The summary statistics of the variables used in the regression and of other relevant variables are in Table 1. As a preliminary step, I regress $A R A$ on three measures of wealth: financial wealth $F W$, that includes all financial assets held by the household in 1995, household net income $F Y$, that includes earnings, pensions and income from real and financial capital ${ }^{8}$, and the dummy $H$, equal to 1 if the household head owns the house he lives in.

Table 1. Means and standard deviations of the main variables.

\begin{tabular}{lcc}
\hline \hline & Mean & Std Dvt \\
\hline \hline $\log y$ & 2.678 & 0.34 \\
$S$ & 10.432 & 3.63 \\
$A$ & 43.132 & 6.60 \\
$A R A$ & 0.153 & 0.09 \\
$F Y$ & 49.756 & 23.72 \\
$F W$ & 30.751 & 62.28 \\
$H$ & 0.669 & - \\
\hline
\end{tabular}

Note: both $F Y$ and $F W$ are in million lire.

The results of this regression are presented in Table 2. As expected, the measure of absolute risk aversion is negatively correlated both with financial

\footnotetext{
${ }^{8}$ Compare this with the variable $y$, that include only (hourly) earnings.
} 
wealth $F W$ and with household income $F Y$. House ownership, on the other hand, is positively but not significantly correlated to risk aversion.

Table 2. OLS regression of $A R A$ on measures of household wealth. Dependent variable: $A R A$

\begin{tabular}{lcc}
\hline \hline & Coefficient & P-value \\
$F W$ & -0.093 & .100 \\
$F Y$ & -0.324 & .033 \\
$H$ & 5.410 & .340 \\
\hline Nobs & 1373 & \\
$R^{2}$ & 0.015 & - \\
\hline \hline
\end{tabular}

Note: Robust standard errors. All the coefficients are multiplied by 1000 .

Notice that the selected measures of wealth absorb only $1.5 \%$ of the total variation of absolute risk aversion. I use the residuals from the regression in Table 2 to construct the variable $R I S K$.

As mentioned above, RISK could affect log earnings, conditional on schooling, by influencing occupational choice. Employment in the available data can be in any of the following occupations: blue collar employee, clerk, school teacher and managerial employee. I order these occupations in the variable $O C C$, using the hourly wage paid in 1995 as the ranking criterion, and I fit an ordered probit model that includes the following explanatory variables: three dummies for attained junior high school $(J U N)$, attained upper secondary school $(H I G H)$ and attained college degree $(C O L L)$, age and RISK. Table 3 shows that occupational choice is strongly influenced by educational attainment. Conditional on education, the choice of occupation is not significantly affected by $R I S K$.

Table 3. Ordered probit of occupational choice. Dependent variable: $O C C$

\begin{tabular}{lcc}
\hline \hline & Coefficient & P-value \\
JUN & 1.082 & .000 \\
HIGH & 2.190 & .000 \\
COLL & 3.703 & .000 \\
A & 0.041 & .000 \\
RISK & -0.432 & .193 \\
\hline Nobs & 1373 & \\
Pseudo $R^{2}$ & 0.25 & \\
\hline \hline
\end{tabular}

Note: robust standard errors are used.

An alternative classification of occupations is between riskier private jobs and safer public jobs. I estimate a probit model where the dependent variable 
is a dummy equal to 1 if the employee works in the public sector and to zero otherwise and the regressors are educational dummies, age and RISK, as in Table 3. Conditional on education, I do not find evidence that RISK significantly affects choice. These results support the selection of $R I S K$ as a valid instrument ${ }^{9}$.

Table 4 presents the results of the reduced form schooling equation. As predicted by theory, I find that, conditional on age, years of schooling are significantly higher for individuals with lower absolute risk aversion, net of wealth effects.

Table 4. OLS estimate of the reduced form schooling equation. Dependent variable: $S$

\begin{tabular}{lcc}
\hline \hline & Coefficient & P-value \\
$A$ & 0.071 & .72 \\
$A^{2}$ & -0.001 & .48 \\
RISK & -2.089 & .04 \\
\hline Nobs & 1373 & \\
$R^{2}$ & 0.02 & \\
\hline \hline
\end{tabular}

Note: robust standard errors are used.

Both OLS and IV estimates of the returns to education are presented in the first four columns of Table 5. It turns out that the estimated returns to schooling based on the IV procedure are about $80 \%$ higher than the returns estimated by standard OLS. This substantial gap cannot be explained by measurement error, that according to Card (1999) accounts for only a $10 \%$ gap.

Since the estimated IV model is just identified, we cannot test for instrument validity. A classical test is the Sargan statistic. This test verifies whether the instruments play a direct role in explaining log wages, not just an indirect role, through predicting educational attainment. If the test fails, one or more of the instruments are invalid and ought to be included in the explanation of log wages.

\footnotetext{
${ }^{9} \mathrm{~A}$ possible objection is that the available classification of occupations is too gross to pick up the different riskiness of jobs. Needless to say, this objection can only by addressed with better data.
} 
Table 5. OLS estimate of (7). Dependent variable: $\ln y$

\begin{tabular}{lcccccc}
\hline \hline & OLS & OLS & IV & IV & IV & IV \\
& {$[1]$} & {$[2]$} & {$[3]$} & {$[4]$} & {$[5]$} & {$[6]$} \\
& Coefficient & P-value & Coefficient & P-value & Coefficient & P-value \\
$S$ & 0.048 & .000 & 0.088 & .039 & 0.088 & .038 \\
$A$ & 0.042 & .009 & 0.039 & .032 & 0.039 & .032 \\
$A^{2}$ & -0.0003 & .049 & -0.0003 & .079 & -0.0003 & .076 \\
\hline Nobs & 1373 & & 1373 & & 1373 & \\
Sargan test & & & & & $0.93(1)$ & \\
$R^{2}$ & 0.29 & & 0.10 & & 0.10 & \\
\hline \hline
\end{tabular}

Note: robust standard errors are used. Degrees of freedom within parentheses.

The additional instrument is provided by a school reform dummy. An important exogenous event in the recent history of Italian education is Law 910 of December 1969, that extended the possibility of enrolment in college to individuals with completed secondary education, independently of the curriculum chosen in secondary school ${ }^{10}$. Since expected age of completion of secondary school is in general 19 years, this opportunity was mainly open to the cohorts born from 1951 onwards. A rough indication of the impact of the reform can be obtained by comparing the percentage of 19 years old individuals enrolling in college shortly before and shortly after the reform. It turns out that enrolment rates were $16.3 \%$ of the relevant population for individuals born in 1949 and $27.3 \%$ for individuals born in $1952^{11}$. At the same time, the percentage of high school graduates enrolling in college was $54 \%$ for the 1949 cohort and $66 \%$ for the 1952 cohort.

I define the dummy $D 51$ as equal to one for individuals born from 1951 onwards and to zero otherwise and use this variable and the variable RISK as instruments for educational attainment in the log earnings regression. The results in the last two columns of Table 5 can be summarized as follows: first, the Sargan test cannot reject the null of instrument validity; second, the estimated returns to education are almost identical to those obtained in the just identified model and are substantially higher than the OLS estimates. This finding confirms the main result in this literature.

\footnotetext{
${ }^{10}$ See Brunello, Comi and Lucifora (1999) for a discussion.

${ }^{11}$ I choose 1949 and 1952 to minimize the risk of including individuals born before 1951 who completed their secondary school later than at the expected age. By taking close years, we also try to reduce the impact of aggregate factors, such as the increase in real income per-capita and the general trend towards more education.
} 


\section{R eferences}

[1] Barsky, R., Juster, T., Kimball, M. and M. Shapiro, (1997), Preference parameters and behavioural heterogeneity: an experimental approach in the health and retirement study, The Quarterly J ournal of Economics, 112, 2, $537-580$

[2] Brunello, G. , Comi, S. and Lucifora, C. , (1999), The Returns to Education in Italy: a New Look at the Evidence, Fondazione ENI Enrico Mattei Working Paper 99-101.

[3] Card, D. (1999), The causal relationship of education on earnings, in Ashenfelter, O. and Card, D., (eds.), Handbook of Labor E conomics, Vol.3, 18011863

[4] Fersterer, J. and Winter Ebmer, R. (2000), Smoking, discount rates and returns to education, IZA Discussion Paper n.126.

[5] Guiso, L. and Paiella, M. (2000), Risk aversion and financial market imperfections, mimeo, Ente Einaudi, Rome.

[6] Harmon, C. and Walker, I., (1995), Estimates of the economic returns to schooling for the United Kingdom, American Economic Review, 85, 12781286 .

[7] Laffont, J.J. (1990), The economics of uncertainty and information, MIT Press. 


\section{IZA Discussion Papers}

\begin{tabular}{|c|c|c|c|c|}
\hline No. & Author(s) & Title & Area & Date \\
\hline 91 & M. Lechner & $\begin{array}{l}\text { Identification and Estimation of Causal Effects of } \\
\text { Multiple Treatments Under the Conditional } \\
\text { Independence Assumption }\end{array}$ & 6 & $12 / 99$ \\
\hline 92 & R. E. Wright & The Rate of Return to Private Schooling & 5 & $12 / 99$ \\
\hline 93 & M. Lechner & $\begin{array}{l}\text { An Evaluation of Public-Sector-Sponsored } \\
\text { Continuous Vocational Training Programs in East } \\
\text { Germany }\end{array}$ & 6 & $12 / 99$ \\
\hline 94 & $\begin{array}{l}\text { M. Eichler } \\
\text { M. Lechner }\end{array}$ & $\begin{array}{l}\text { An Evaluation of Public Employment Programmes } \\
\text { in the East German State of Sachsen-Anhalt }\end{array}$ & 6 & $12 / 99$ \\
\hline 95 & $\begin{array}{l}\text { P. Cahuc } \\
\text { A. Zylberberg }\end{array}$ & Job Protection, Minimum Wage and Unemployment & 3 & $12 / 99$ \\
\hline 96 & $\begin{array}{l}\text { P. Cahuc } \\
\text { A. Zylberberg }\end{array}$ & $\begin{array}{l}\text { Redundancy Payments, Incomplete Labor } \\
\text { Contracts, Unemployment and Welfare }\end{array}$ & 3 & $12 / 99$ \\
\hline 97 & A. Barrett & $\begin{array}{l}\text { Irish Migration: Characteristics, Causes and } \\
\text { Consequences }\end{array}$ & 1 & $12 / 99$ \\
\hline 98 & $\begin{array}{l}\text { J.P. Haisken-DeNew } \\
\text { C. M. Schmidt }\end{array}$ & $\begin{array}{l}\text { Industry Wage Differentials Revisited: A } \\
\text { Longitudinal Comparison of Germany and USA }\end{array}$ & $1 / 5$ & $12 / 99$ \\
\hline 99 & R. T. Riphahn & $\begin{array}{l}\text { Residential Location and Youth Unemployment: } \\
\text { The Economic Geography of School-to-Work- } \\
\text { Transitions }\end{array}$ & 1 & $12 / 99$ \\
\hline 100 & $\begin{array}{l}\text { J. Hansen } \\
\text { M. Lofstrom }\end{array}$ & $\begin{array}{l}\text { Immigrant Assimilation and Welfare Participation: } \\
\text { Do Immigrants Assimilate Into or Out-of Welfare? }\end{array}$ & $1 / 3$ & $12 / 99$ \\
\hline 101 & $\begin{array}{l}\text { L. Husted } \\
\text { H. S. Nielsen } \\
\text { M. Rosholm } \\
\text { N. Smith }\end{array}$ & $\begin{array}{l}\text { Employment and Wage Assimilation of Male First } \\
\text { Generation Immigrants in Denmark }\end{array}$ & 3 & $1 / 00$ \\
\hline 102 & $\begin{array}{l}\text { B. van der Klaauw } \\
\text { J. C. van Ours }\end{array}$ & $\begin{array}{l}\text { Labor Supply and Matching Rates for Welfare } \\
\text { Recipients: An Analysis Using Neighborhood } \\
\text { Characteristics }\end{array}$ & $2 / 3$ & $1 / 00$ \\
\hline 103 & K. Brännäs & $\begin{array}{l}\text { Estimation in a Duration Model for Evaluating } \\
\text { Educational Programs }\end{array}$ & 6 & $1 / 00$ \\
\hline 104 & S. Kohns & $\begin{array}{l}\text { Different Skill Levels and Firing Costs in a } \\
\text { Matching Model with Uncertainty - } \\
\text { An Extension of Mortensen and Pissarides (1994) }\end{array}$ & 1 & $1 / 00$ \\
\hline 105 & $\begin{array}{l}\text { G. Brunello } \\
\text { C. Graziano } \\
\text { B. Parigi }\end{array}$ & $\begin{array}{l}\text { Ownership or Performance: What Determines } \\
\text { Board of Directors' Turnover in Italy? }\end{array}$ & 1 & $1 / 00$ \\
\hline
\end{tabular}


1979 - 1990: An analysis of the (West-)German multivariate failure times and unobserved heterogeneity

107 J. C. van Ours G. Ridder

J. Boone

J. C. van Ours

109 G. J. van den Berg

B. van der Klaauw

110 D. DeVoretz

C. Werner

111 V. Sorm

K. Terrell

112

L. Bellmann

T. Schank

113 R. Euwals

114 G. Brunello

A. Medio

115 A. Cigno

F. C. Rosati

116

C. Belzil

S. Bender

A. Haas

C. Klose

118 M. A. Shields

M. E. Ward

119 A. Lindbeck

D. J. Snower

120 P. T. Pereira

P. S. Martins

121

J. C. van Ours

122

D. Munich

J. Svejnar

K. Terrell

123 J. Hunt
Fast Track or Failure: A Study of the Completion

Rates of Graduate Students in Economics

Modeling Financial Incentives to Get Unemployed Back to Work

Combining Micro and Macro Unemployment

Duration Data

A Theory of Social Forces and Immigrant Second

Language Acquisition

Sectoral Restructuring and Labor Mobility:

A Comparative Look at the Czech Republic

Innovations, Wages and Demand for

5

$1 / 00$

Heterogeneous Labour: New Evidence from a

Matched Employer-Employee Data-Set

Do Mandatory Pensions Decrease Household

Savings? Evidence for the Netherlands

An Explanation of International Differences in

Education and Workplace Training

Why do Indian Children Work, and is it Bad for

3

$2 / 00$

Them?

Unemployment Insurance and Subsequent Job

Duration: Job Matching vs. Unobserved

Heterogeneity

IAB Employment Subsample 1975-1995.

Opportunities for Analysis Provided by the

Anonymised Subsample

Improving Nurse Retention in the British National

Health Service: The Impact of Job Satisfaction on

5

$2 / 00$

Intentions to Quit

The Division of Labor and the Market for

Organizations

Does Education Reduce Wage Inequality?

Quantile Regressions Evidence from Fifteen

European Countries

3

$2 / 00$

$2 / 00$

Do Active Labor Market Policies Help Unemployed $\quad 4 / 6 \quad 3 / 00$

Workers to Find and Keep Regular Jobs?

Returns to Human Capital under the Communist

Wage Grid and During the Transition to a Market

4

$3 / 00$

Economy

Why Do People Still Live in East Germany? 
125 F. Büchel of Social Assistance Benefits

J. R. Frick

The Income Portfolio of Immigrants in Germany $1 / 3$

$3 / 00$

Effects of Ethnic Origin and Assimilation. Or:

Who Gains from Income Re-Distribution?

126 J. Fersterer

Smoking, Discount Rates, and Returns to

R. Winter-Ebmer

Education

127 M. Karanassou

Characteristics of Unemployment Dynamics: The

Chain Reaction Approach

D. J. Snower

Do Unemployment Insurance Recipients Actively

Seek Work? Evidence From Randomized Trials in

Four U.S. States

129 B. R. Chiswick

M. E. Hurst

The Employment, Unemployment and

Unemployment Compensation Benefits of

Immigrants

130 G. Brunello

S. Comi

C. Lucifora

The Returns to Education in Italy: A New Look at

5

$3 / 00$

the Evidence

131 B. R. Chiswick

132

R. A. Hart

Are Immigrants Fa

Hours and Wages in the Depression: British 7

133 D. N. F. Bell

Paid and Unpaid Overtime Working in Germany and 1

R. A. Hart

O. Hübler

W. Schwerdt

the UK

134 A. D. Kugler

G. Saint-Paul

135 A. Barrett

P. J. O'Connell

136 M. Bräuninger

M. Pannenberg

Hiring and Firing Costs, Adverse Selection and

3

$3 / 00$

Long-term Unemployment

Is There a Wage Premium for Returning Irish

$3 / 00$

Migrants?

Unemployment and Productivity Growth: An

$3 / 00$

Empirical Analysis within the Augmented Solow

3

Model

137 J.-St. Pischke

Continuous Training in Germany

138 J. Zweimüller

R. Winter-Ebmer

Firm-specific Training: Consequences for Job

Mobility

139 R. A. Hart

Y. Ma

Wages, Hours and Human Capital over the

$3 / 00$

140 G. Brunello

Life Cycle

1

Education and Earnings Growth: Evidence from $11 \quad$ 2/5 4/00

S. Comi

European Countries

141 R. Hujer

M. Wellner

The Effects of Public Sector Sponsored Training on

Individual Employment Performance in East

6

$4 / 00$

Germany 

both Worlds?

Does the Recent Success of Some OECD Countries in Lowering their Unemployment Rates Lie in the Clever Design of their Labour Market Reforms?

Employment Effects of Labour Taxation in an Efficiency Wage Model with Alternative Budget Constraints and Time Horizons

149 R. Lalive

J. C. van Ours

J. Zweimüller

150 J. DiNardo

K. F. Hallock

J.-St. Pischke

$151 \quad$ M. Ward

152 J. J. Dolado

F. Felgueroso

J. F. Jimeno

153 A. S. Kalwij

M. Gregory

154 M. Gerfin

M. Lechner

155 J. Hansen

156 C. Dustmann

F. Fabbri

157 P. Apps

R. Rees

158 A. Björklund

T. Eriksson

M. Jäntti

O. Raaum

E. Österbacka

The Impact of Active Labor Market Programs and Benefit Entitlement Rules on the Duration of

Unions and the Labor Market for Managers

Gender, Salary and Promotion in the Academic Profession

The Role of the Minimum Wage in the Welfare 3

Microeconometric Evaluation of the Active Labour 6

The Duration of Immigrant
Evidence from Sweden

Language Proficiency and Labour Market Per- 1

formance of Immigrants in the UK

Household Production, Full Consumption and $\quad 7$ the Costs of Children

Brother Correlations in Earnings in Denmark, 5 Finland, Norway and Sweden Compared to the United States 
A Comparison of the Human Capital and Signaling Models: The Case of the Self-Employed and the Barrachina

Selection Correction in Panel Data Models: An Application to Labour Supply and Wages The Recent Danish Experience

Wages and the Demand for Health - A Life Cycle Analysis

Reforming the Financial Incentives of the Welfare System Skilled Immigrants in the United States 
177 B. R. Chiswick

G. Repetto

178 R. Euwals M. Ward

179 E. Wasmer

P. Weil

180 T. K. Bauer

I. N. Gang

181 E. Wasmer

Y. Zenou

182 M. Fertig

C. M. Schmidt

183 M. Fertig

C. M. Schmidt

184 M. Corak

B. Gustafsson

T. Österberg

185 H. Bonin

K. F. Zimmermann

186

C. Dustmann

187

T. K. Bauer

M. Lofstrom

K. F. Zimmermann

188 A. Kapteyn

A. S. Kalwij

A. Zaidi

189 W. Arulampalam

190 C. Dustmann

I. Preston

191 G. C. Giannelli

C. Monfardini

192

G. Brunello
Immigrant Adjustment in Israel: Literacy and

Fluency in Hebrew and Earnings

The Renumeration of British Academics

The Macroeconomics of Labor and Credit Market Imperfections

Sibling Rivalry in Educational Attainment:

The German Case

Space, Search and Efficiency

Discretionary Measures of Active Labor Market

Policy: The German Employment Promotion Reform in Perspective

Aggregate-Level Migration Studies as a Tool for 1 Forecasting Future Migration Streams

Intergenerational Influences on the Receipt of

Unemployment Insurance in Canada and Sweden

The Post-Unification German Labor Market

Temporary Migration and Economic Assimilation

Immigration Policy, Assimilation of Immigrants and Natives' Sentiments towards Immigrants: Evidence from 12 OECD-Countries

The Myth of Worksharing

Is Unemployment Really Scarring? Effects of

Unemployment Experiences on Wages

Racial and Economic Factors in Attitudes to Immigration

Joint Decisions on Household Membership and Human Capital Accumulation of Youths: The role of expected earnings and local markets

Absolute Risk Aversion and the Returns to Education
2

$8 / 00$

3

4

$8 / 00$

$8 / 00$

5

$8 / 00$

3

$8 / 00$

1

$8 / 00$

5

7/00

$7 / 00$

$8 / 00$

$8 / 00$

$8 / 00$

$8 / 00$

$8 / 00$

$8 / 00$

.

100

$5 \quad 8 / 00$ 